\title{
Improving The Slovenian Healthcare System By Examining Other European Healthcare Systems
}

Stanka Setnikar Cankar, Ph.D., University of Ljubljana, Slovenia Veronika Petkovšek, University of Ljubljana, Slovenia

\begin{abstract}
This paper focuses improving the Slovenian healthcare system by comparing it with the systems in place in the UK, Denmark, and France. The aim of the paper is to find and present the solutions required if the healthcare system in Slovenia is to be improved. Changes need to be made to the organisation, management, and financing of the Slovenian healthcare system in response to demographic changes and changes to the age structure of the population, the rapid development of new medical technologies, drugs, treatments, and globalisation. The paper outlines the main features of the Slovenian healthcare system and compares the structure of public and private expenditure and resources with the structures in place in the UK, Denmark, and France. Public and private healthcare providers and public-private partnerships in Slovenian healthcare are also presented and compared. An insight is given at the end of the paper into the current state of the Slovenian healthcare system and the required changes, with solutions proposed for improvements and reform. The proposed solutions include redefinition of an insured person's status, changes to the insurance basis and rates, a redefinition of the basic basket of healthcare rights, the integration and networking of public healthcare institutions, and the separation of public and private healthcare providers.
\end{abstract}

Keywords: Healthcare; Healthcare Spending; Public-Private Partnership; Healthcare Reform; Slovenian Healthcare System; European Healthcare Systems

\section{INTRODUCTION}

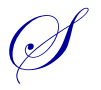

lovenia is facing an increased need and demand for health services; this necessitates higher healthcare expenditure. Demographic, socio-economic, medical, pharmaceutical, technological and other trends present the biggest challenge, leading to a growth in healthcare costs. Increasing demand for healthcare services is the result of the ageing of the population and the rapid development of science and technology. With the increase in the proportion of older people come more chronic and degenerative diseases; these require treatment as acute illnesses (Prevolnik-Rupel, Marušič \& Turk, 2012, p. 36). Maintaining public health service provision at an adequate level creates pressure to modernise medical procedures more quickly. Technology can mean greater financial investment and greater effectiveness of treatment; the result of these pressures, however, is a rapid increase in the costs of healthcare (Poslovno poročilo ZZZS za leto 2009/2009 Business Report of the Health Insurance Institute of Slovenia, 2010, pp. 14-15, 18).

Rising healthcare expenditure reminds us that changes to healthcare financing and provision are necessary if a sustainable healthcare system is to be maintained (Prevolnik-Rupel, Marušič \& Turk, 2012, p. 35). The Slovenian healthcare system is faced with a sub-optimal utilisation of healthcare system resources, poor management and a lack of public-private partnership, the latter being one of the fundamental instruments and measures for reducing public healthcare expenditure, increasing quality, efficiency and effectiveness, and improving management (Setnikar Cankar \& Petkovšek, 2012, p. 56). 


\section{HEALTHCARE SYSTEM IN SLOVENIA}

Slovenia has a network of public and private healthcare providers at the primary, secondary, and tertiary levels. The basic principles of healthcare in Slovenia are solidarity, non-profit, and social justice. The principle of solidarity means that the users of the system must receive equal treatment regardless of their ability to pay (Tajnikar, 2009, p. 6).

The Slovenian healthcare system is based on social health insurance. All citizens and inhabitants of Slovenia are included in a compulsory health insurance scheme, which provides insured parties with two basic sets of rights: healthcare rights and rights to cash benefits or reimbursements. Alongside compulsory health insurance, voluntary supplementary health insurance is also available. The 'health security' of insured persons is based on adequate access to services and a reasonable level of healthcare quality. A steady supply of physicians and health facilities within the population is very important (Poslovno poročilo ZZZS za leto 2009/2009 Business Report of the Health Insurance Institute of Slovenia, 2010, pp. 16, 36).

\section{HEALTHCARE SPENDING IN SLOVENIA}

Since the introduction of voluntary health insurance, the proportion of public spending on healthcare in Slovenia has fallen, while private spending has increased. The burden of additional healthcare financing has primarily shifted to private expenditure by the population in the form of voluntary health insurance and direct payments. Access to healthcare in Slovenia is increasing with the increase in direct payments. In 2010 private healthcare spending made up $29.28 \%$ of total healthcare spending in Slovenia, with direct payments by households accounting for $12.94 \%$ and spending on voluntary health insurance accounting for $13.33 \%$. Total healthcare spending amounted to $9.06 \%$ of GDP in Slovenia in 2010 and the share of public healthcare spending in total healthcare was $70.72 \%$ (6.41\% of GDP) in the same year. The estimate for 2011 shows that public healthcare spending stayed at the same level as in 2010, at $6.4 \%$ of GDP, while the share of public healthcare spending in total healthcare spending rose to $71.4 \%$. Private healthcare spending fell to $2.6 \%$ of GDP in 2011 and private healthcare spending as a proportion of total spending on healthcare also fell to $28.6 \%$ in the same year. Within private healthcare spending, the share of direct payments in total spending on healthcare grew to 13.7\% in 2011 (European Health for All Database (HFA-DB), 2012; Prva statistična objava/First Statistical Report, 2010; Poslovno poročilo ZZZS za leto 2010/2010 Business Report of the Health Insurance Institute of Slovenia, 2011, p. 146; Poslovno poročilo ZZZS za leto 2011/2011 Business Report of the Health Insurance Institute of Slovenia, 2012, p. 144).

Table 1: Healthcare spending in Slovenia 2005-2011

\begin{tabular}{|l|c|c|c|c|c|}
\hline Year & $\begin{array}{c}\text { Total healthcare } \\
\text { spending } \\
\text { (\% of GDP) }\end{array}$ & $\begin{array}{c}\text { Public healthcare } \\
\text { spending } \\
(\% \text { of GDP) }\end{array}$ & $\begin{array}{c}\text { Public healthcare } \\
\text { spending }(\% \text { of } \\
\text { total healthcare } \\
\text { spending) }\end{array}$ & $\begin{array}{c}\text { Private healthcare } \\
\text { spending } \\
\text { (\% of GDP) }\end{array}$ & $\begin{array}{c}\text { Private healthcare } \\
\text { spending }(\% \text { of } \\
\text { total healthcare } \\
\text { spending) }\end{array}$ \\
\hline 2005 & 8.7 & 6.3 & 71.9 & 2.4 & 28.1 \\
\hline 2006 & 8.6 & 6.3 & 72.4 & 2.3 & 27.6 \\
\hline 2007 & 8.1 & 5.9 & 71.6 & 2.2 & 28.4 \\
\hline 2008 & 8.3 & 6.1 & 72.0 & 2.2 & 28.1 \\
\hline 2009 & 9.2 & 6.6 & 72.0 & 2.6 & 2.7 \\
\hline 2010 & 9.1 & 6.4 & 70.7 & 2.7 & 29.3 \\
\hline $2011^{*}$ & 9.0 & 6.4 & 71.4 & 2.6 & \\
\hline
\end{tabular}

*estimate

Sources: Statistični letopis 2010/2010 Statistical Yearbook, European Health for All Database (HFA-DB), 2012; Poslovno poročilo ZZZS za leto 2010/2010 Business Report of the Health Insurance Institute of Slovenia, 2011, p. 146; Poslovno poročilo ZZZS za leto 2011/2011 Business Report of the Health Insurance Institute of Slovenia, 2012, p. 144. 
Table 2: Direct payments in healthcare in Slovenia 2005-2011

\begin{tabular}{|l|c|c|c|}
\hline Year & $\begin{array}{c}\text { Private healthcare spending (\% of } \\
\text { total healthcare spending) }\end{array}$ & $\begin{array}{c}\text { Direct payments (\% of total } \\
\text { healthcare spending) }\end{array}$ & $\begin{array}{c}\text { Direct payments (\% of private } \\
\text { healthcare spending) }\end{array}$ \\
\hline 2005 & 28.1 & 12.5 & 44.4 \\
\hline 2006 & 27.6 & 11.8 & 42.8 \\
\hline 2007 & 28.4 & 13.8 & 48.6 \\
\hline 2008 & 28.1 & 12.7 & 45.2 \\
\hline 2009 & 28.0 & 12.7 & 45.2 \\
\hline 2010 & 29.3 & 12.9 & 44.2 \\
\hline $2011^{*}$ & 28.6 & 13.7 & 47.8 \\
\hline
\end{tabular}

*estimate

Sources: European Health for All Database (HFA-DB), 2012; Poslovno poročilo ZZZS za leto 2010/2010 Business Report of the Health Insurance Institute of Slovenia, 2011, p. 146; Poslovno poročilo ZZZS za leto 2011/2011 Business Report of the Health Insurance Institute of Slovenia, 2012, p. 144.

\section{FUNDING OF HEALTHCARE IN SLOVENIA}

Slovenia has a mixed, public-private model of funding for healthcare. Healthcare is financed from public and private sources (compulsory and voluntary health insurance) and from direct payments (Obvezno zdravstveno zavarovanje v Sloveniji: danes za jutri/Compulsory Health Insurance in Slovenia - Today for Tomorrow, 2007, pp. $11,45)$. The problems that occur when funding healthcare through compulsory health insurance have increased the pressure for supplementary payments to become usual practice and an increasing source of regular healthcare funding (Tajnikar \& Došenovič Bonča, 2010, p. 2).

Most healthcare funding in Slovenia is provided from public sources, which in 2011 represented around $71 \%$ of total healthcare spending. Most of these public resources come from compulsory health insurance, which accounted for almost $67 \%$ of total healthcare spending in 2011 . The remainder of public expenditure is provided from municipal and national budgets, which together accounted for around $4.7 \%$ of total spending in 2011. A significant proportion of healthcare spending also comes from private resources, which account for $28.6 \%$ of total spending on healthcare (2011 estimate). Most of the private resources are contributed by insurance companies offering voluntary health insurance, with other private expenditure comprising spending on various goods and health services that people in Slovenia pay for directly (Poslovno poročilo ZZZS za leto 2010/2010 Business Report of the Health Insurance Institute of Slovenia, 2011, p. 146; Poslovno poročilo ZZZS za leto 2011/2011 Business Report of the Health Insurance Institute of Slovenia, 2012, p. 144).

Table 3: Funding of healthcare in Slovenia 2009-2011

\begin{tabular}{|c|c|c|c|c|c|c|}
\hline & \multicolumn{2}{|c|}{2009} & \multicolumn{2}{|c|}{2010} & \multicolumn{2}{|c|}{ 2011* } \\
\hline & $\begin{array}{l}\text { Structure } \\
\text { in } \%\end{array}$ & $\%$ of GDP & $\begin{array}{l}\text { Structure } \\
\text { in \% }\end{array}$ & $\%$ of GDP & $\begin{array}{l}\text { Structure } \\
\text { in } \%\end{array}$ & $\%$ of GDP \\
\hline Total healthcare funding & 100.00 & 9.16 & 100.00 & 9.06 & 100.00 & 9.02 \\
\hline Public funding & 71.96 & 6.59 & 70.72 & 6.41 & 71.40 & 6.44 \\
\hline National budget funds & 3.72 & 0.34 & 2.80 & 0.26 & 3.89 & 0.35 \\
\hline Municipal budget funds & 0.90 & 0.08 & 0.85 & 0.08 & 0.85 & 0.08 \\
\hline $\begin{array}{l}\text { Compulsory health } \\
\text { insurance }\end{array}$ & 67.34 & 6.17 & 67.07 & 6.07 & 66.66 & 6.01 \\
\hline Private funding & 28.04 & 2.57 & 29.28 & 2.65 & 28.60 & 2.58 \\
\hline Voluntary health insurance & 12.42 & 1.14 & 13.33 & 1.21 & 13.68 & 1.23 \\
\hline Direct payments & 12.68 & 1.16 & 12.94 & 1.17 & 13.67 & 1.23 \\
\hline $\begin{array}{l}\text { Companies (excluding } \\
\text { insurers) and non-profit } \\
\text { institutions }\end{array}$ & 2.94 & 0.27 & 3.01 & 0.27 & 1.25 & 0.12 \\
\hline
\end{tabular}

*estimate

Sources: Poslovno poročilo ZZZS za leto 2010/2010 Business Report of the Health Insurance Institute of Slovenia, 2011, p. 146;

Poslovno poročilo ZZZS za leto 2011/2011 Business Report of the Health Insurance Institute of Slovenia, 2012, p. 144. 


\section{Funding of healthcare in the UK, France, and Denmark -comparison with Slovenia}

In Slovenia and France, social security resources are the main source of public funding for healthcare. In 2009 social security resources (compulsory health insurance) accounted for $67.34 \%$ of all healthcare funding in Slovenia; in France, social security resources (the public health insurance scheme) accounted for $72.5 \%$ of all healthcare funding. In the UK and Denmark, most public healthcare funding comes from tax: $83.63 \%$ of all healthcare funding in the UK and 84.46\% of all healthcare funding in Denmark (2009 figures, Eurostat, 2012).

Table 4: Funding of healthcare in Slovenia, the UK, France, and Denmark in 2009

\begin{tabular}{|l|c|c|c|c|c|c|c|c|}
\hline & \multicolumn{2}{|c|}{ Slovenia } & \multicolumn{2}{c|}{ Denmark } & \multicolumn{2}{c|}{ France } & \multicolumn{2}{c|}{ UK } \\
\hline & $\begin{array}{c}\text { Structure } \\
\text { in \% }\end{array}$ & $\begin{array}{c}\text { \% of } \\
\text { GDP }\end{array}$ & $\begin{array}{c}\text { Structure } \\
\text { in \% }\end{array}$ & $\begin{array}{c}\text { \% of } \\
\text { GDP }\end{array}$ & $\begin{array}{c}\text { Structure } \\
\text { in \% }\end{array}$ & $\begin{array}{c}\text { Structure } \\
\text { GDP }\end{array}$ & $\begin{array}{c}\text { \% of } \\
\text { GDP }\end{array}$ \\
\hline $\begin{array}{l}\text { Total healthcare } \\
\text { funding }\end{array}$ & $\mathbf{1 0 0 . 0 0}$ & $\mathbf{9 . 1 6}$ & $\mathbf{1 0 0 . 0 0}$ & $\mathbf{1 1 . 1 0}$ & $\mathbf{1 0 0 . 0 0}$ & $\mathbf{1 1 . 6 0}$ & $\mathbf{1 0 0 . 0 0}$ & $\mathbf{8 . 9 0}$ \\
\hline Public funding & $\mathbf{7 1 . 9 6}$ & $\mathbf{6 . 5 9}$ & $\mathbf{8 4 . 4 6}$ & $\mathbf{9 . 3 7}$ & $\mathbf{7 8 . 1 0}$ & $\mathbf{9 . 0 4}$ & $\mathbf{8 3 . 6 3}$ & $\mathbf{7 . 7 0}$ \\
\hline $\begin{array}{l}\text { Government } \\
\text { funding } \\
\text { (excluding social } \\
\text { security } \\
\text { resources) }\end{array}$ & 4.62 & 0.42 & 84.46 & 9.37 & 5.6 & 0.65 & 83.63 & n.p. \\
\hline $\begin{array}{l}\text { Social security } \\
\text { resources }\end{array}$ & 67.34 & 6.17 & 0.00 & 0.00 & 72.5 & 8.39 & 0.00 & n.p. \\
\hline Private funding & $\mathbf{2 8 . 0 4}$ & $\mathbf{2 . 5 7}$ & $\mathbf{1 5 . 5 4}$ & $\mathbf{1 . 7 3}$ & $\mathbf{2 1 . 9 0}$ & $\mathbf{2 . 5 6}$ & $\mathbf{1 6 . 3 7}$ & $\mathbf{1 . 2 0}$ \\
\hline $\begin{array}{l}\text { Insurance } \\
\text { companies }\end{array}$ & 12.42 & 1.14 & 1.79 & 0.21 & 13.63 & 1.58 & 1.10 & n.p. \\
\hline Direct payments & 12.68 & 1.16 & 13.68 & 1.52 & 7.51 & 0.87 & 10.66 & n.p. \\
\hline Other & 2.94 & 0.27 & 0.07 & 0.00 & 0.76 & 0.11 & 4.61 & n.p. \\
\hline
\end{tabular}

Source: Setnikar Cankar \& Petkovšek, 2012, p. 64.

There are two ways of funding public healthcare in the countries selected: through social security resources (Slovenia and France) and taxation (Denmark and the UK). Denmark and the UK generate around 15\% more public funding for healthcare through taxes than Slovenia and France do from social security resources. Differences are also seen in the structure of private funding for healthcare. Supplementary health insurance represents a significant share of private funding in Slovenia and France, while the share in Denmark and the UK is much smaller (Setnikar Cankar \& Petkovšek, 2012, p. 78).

\section{Public and private healthcare providers in Slovenia}

Slovenia has two parallel healthcare systems: public and private. Up until 1992, healthcare was provided exclusively by public healthcare institutions; since then, private healthcare provision within public healthcare has been made possible by the awarding of concessions. Some private service providers operate entirely on the market, while others operate within the publicly financed healthcare system. The proportion of healthcare service providers in private ownership in Slovenia has increased in recent years, particularly within the public healthcare network (Socialni razgledi 2009/2009 Social Monitor, pp. 43-44).

The number of private concession-holders has increased throughout the whole period, with the exception of 2011, when the number fell slightly. In 2010 the Health Insurance Institute of Slovenia concluded contracts with 1,789 providers (223 public institutions and 1,566 private concession-holders). The number of private contractual partners increased by seven in 2010. In 2011 the Health Insurance Institute of Slovenia concluded contracts with 1,784 providers (224 public institutions and 1,560 private concession-holders). The number of private contractual partners fell by six in 2011 (Poslovno poročilo ZZZS za leto 2011/2011 Business Report of the Health Insurance Institute of Slovenia, 2012, p. 143). 


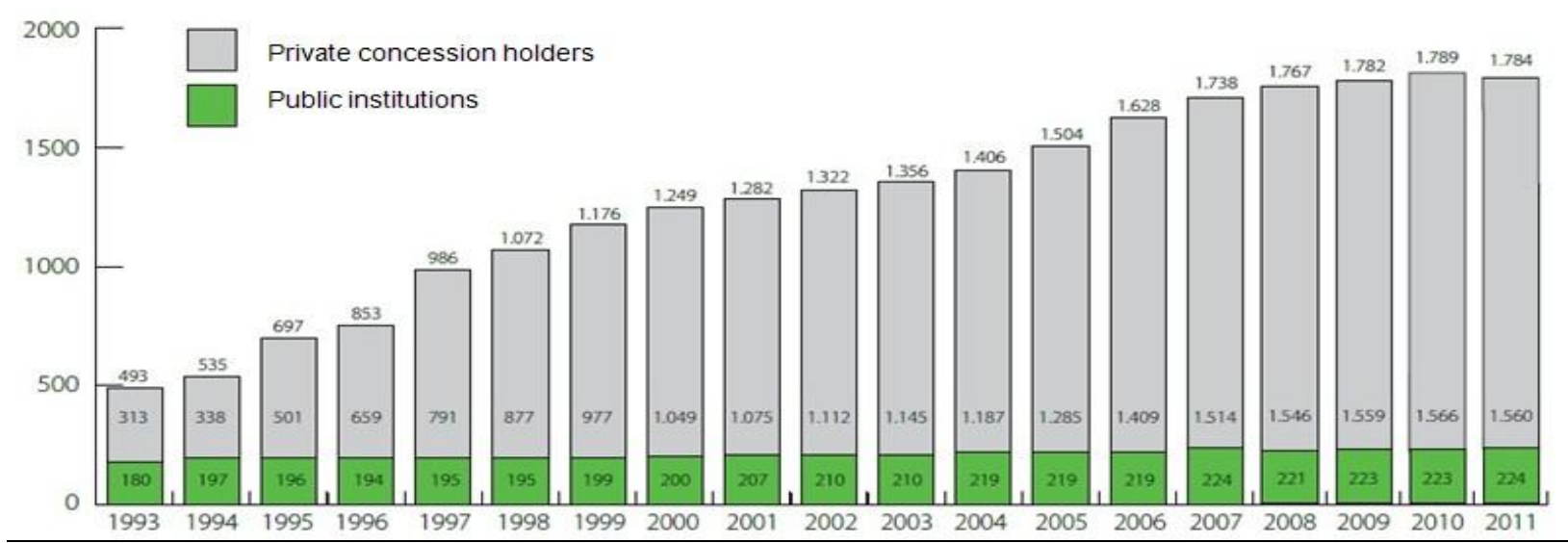

Figure 1: Number of contracts with private concession-holders and public healthcare institutions in Slovenia 1993-2011 Source: Poslovno poročilo ZZZS za leto 2011/2011 Business Report of the Health Insurance Institute of Slovenia, 2012 , p. 143.

\section{Public-private partnership in Slovenian healthcare}

Public-private partnership (PPP) in healthcare brings together public and private partners with the aim of improving the health of the population and enables the transfer of part of the risk to the private sector, thus indirectly relieving the pressure on public finances. Owing to increases in healthcare expenditure, PPP in healthcare is a very welcome development. Cooperation between the public and private sectors is particularly beneficial in the area of hospital performance and can have a significant impact on controlling costs and improving service quality when public hospitals are constructed and managed jointly (Setnikar Cankar \& Petkovšek, 2012, pp. 67-68).

PPP is able to meet the requirement for investment in health infrastructure to improve healthcare services and cover increased healthcare needs. It can take different forms in healthcare, with varying degrees of transfer of responsibilities and risks between the public and private sectors. The private partner may be liable for all or some of the activities of the project; funding may be provided by the private or public sector, or indeed by both. The most common forms of PPP in healthcare are: contracts, concessions and private finance initiatives. By involving the private sector in public healthcare, we can reduce public spending, achieve greater efficiency and effectiveness, increase cost-effectiveness and improve healthcare management. Private sector involvement also brings fresh perspectives and the technical and professional skills required for management. All this can lead to improved health service quality (Experience with PPP Projects in Healthcare, 2010, p. 10; Navarro Espigarez \& Hernández Torres, 2009, pp. 11-12).

Cooperation between the public and private sectors in healthcare in Slovenia has so far mostly been carried out in the form of concessions. In addition to healthcare concessions, institutions also frequently outsource support and non-medical services to private providers (public procurement). The co-investment of private capital has occurred only very rarely in Slovenian healthcare. The main motive for public sector projects within PPP is to provide funds for investment and provide better services to users within the context of limited public resources. Fiscal pressures will lead to an increasing need for alternative sources of healthcare funding, particularly for investment in health facilities, with particular emphasis on medical equipment and facilities (Setnikar Cankar \& Petkovšek, 2012, pp. 70, 72).

\section{PPP in the UK, France, and Denmark - comparison with Slovenia}

In the UK, PPP has been part of the healthcare sector since 1997; in that time, there have been more than 100 examples of PPP in healthcare. The most common form of PPP in healthcare in the UK is the private finance initiative, whose purpose is not only to finance capital investments but also to exploit the full range of private sector management, business and creative skills. In France, as in Slovenia, PPP in healthcare is at an early stage of development, having been introduced in 2004. The basic contractual structure for hospital projects in PPP under the 'Hôpital 2007' programme is the long-term lease (between 18 and 99 years) negotiated at the local level, which 
allows property/facilities in the public domain to be temporarily owned by the private partner, with the obligation to return it free-of-charge to health authorities at the end of the period. PPP in healthcare in Denmark is currently confined to the establishment of a national e-health portal based on a profit-oriented IT contract. The public sector project partner is the Danish state, including the main healthcare actors; the private sector is made up of a consortium of private partners. The chief benefits of PPP in this project are increased system integration and a reduction in transaction costs (Setnikar Cankar \& Petkovšek, 2012, pp. 75-76).

Table 5: PPP in healthcare in Slovenia, the UK, France and Denmark

\begin{tabular}{|l|l|l|l|l|}
\hline & \multicolumn{1}{|c|}{ Slovenia } & \multicolumn{1}{|c|}{ UK } & \multicolumn{1}{c|}{ France } & \multicolumn{1}{c|}{ Denmark } \\
\hline Status of PPP & $\begin{array}{l}\text { Initial stage of } \\
\text { development }\end{array}$ & $\begin{array}{l}\text { More than 100 cases } \\
\text { of PPP }\end{array}$ & $\begin{array}{l}\text { Initial stage of } \\
\text { development }\end{array}$ & $\begin{array}{l}\text { Initial stage of } \\
\text { development }\end{array}$ \\
\hline $\begin{array}{l}\text { Most common } \\
\text { form of PPP }\end{array}$ & $\begin{array}{l}\text { Concession and public } \\
\text { procurement }\end{array}$ & $\begin{array}{l}\text { Private finance } \\
\text { initiative }\end{array}$ & $\begin{array}{l}\text { Long-term lease } \\
\text { Profit-oriented IT } \\
\text { contract }\end{array}$ \\
\hline $\begin{array}{l}\text { in healthe of PPP } \\
\text { The construction of a } \\
\text { dialysis centre at Sežana } \\
\text { Hospital, with the private } \\
\text { investor carrying out the } \\
\text { construction work and } \\
\text { purchasing equipment } \\
\text { for the centre. }\end{array}$ & $\begin{array}{l}\text { The renovation of two } \\
\text { old and substandard } \\
\text { hospitals in London } \\
\text { (St. Bartholomew's } \\
\text { and the Royal } \\
\text { London). The project } \\
\text { involves three private } \\
\text { partners. }\end{array}$ & $\begin{array}{l}\text { The 'Hôpital 2007 } \\
\text { programme, which } \\
\text { provides incentives for } \\
\text { investment to improve } \\
\text { healthcare services. }\end{array}$ & $\begin{array}{l}\text { National e-health portal. } \\
\text { Cooperation between } \\
\text { public partners (the } \\
\text { Danish state and the main } \\
\text { healthcare actors) and a } \\
\text { consortium of private } \\
\text { partners. }\end{array}$ \\
\hline
\end{tabular}

Source: Setnikar Cankar \& Petkovšek, 2012, p. 64.

\section{HEALTHCARE REFORM IN SLOVENIA}

The healthcare system in Slovenia needs a radical overhaul in terms of the organisation, management, and financing of general and long-term care. Particular attention must be paid to the quality and efficiency of healthcare performance. A proper system of efficiency control is required, in line with the characteristics, goals and challenges of Slovenian healthcare (Devjak \& Bencina, 2012, pp. 107-108); another of the long-term key goals is the provision of full computerised support to healthcare. The successful implementation of computerised support projects can have a very significant national and strategic impact on the further development of the healthcare system (Stanimirović \& Vintar, 2012, p. 217).

\section{Current situation and improvements to the Slovenian healthcare system}

The current healthcare system in Slovenia has not changed a great deal since 1992. It is still rigid and inflexible, and its financial sustainability is questionable. The requirement to change the healthcare system results from the need to develop and from demographic changes and changes to the age structure of the population, the rapid development of new medical technologies, drugs and treatments, and globalisation. Changes are also necessary because of the inadequate staffing policy (and, indeed, the lack of adequate staff), a lack of appropriate legislative amendments that will introduce changes to the system, the introduction of supplementary health insurance, a partial transfer of funding for healthcare services to the supplementary health insurance system, and inadequate investments in healthcare (Vlada Republike Slovenije/Government of the Republic of Slovenia, 2012). The current situation in Slovenian healthcare makes it necessary to introduce legislative changes to adapt to the need for and the development requirements of a flexible healthcare system - one which can effectively meet the needs of citizens (Grgorič Rogelj, 2012).

In light of these necessary changes to the Slovenian healthcare system, we will highlight some examples of good practice in the UK, France, and Denmark. All these countries, like Slovenia, provide their citizens with public health services, while Slovenia also provides private health services within the public health system on the basis of concessions. Denmark, France, and the UK all have a comprehensive public healthcare system - one in which every citizen is entitled to public healthcare. Public healthcare in Slovenia and France is financed mainly by social security resources (compulsory health insurance in Slovenia, public health insurance schemes in France), while in Denmark and the UK, public healthcare services are funded by taxation. Since not all public healthcare services are free, or are only partly free, the countries studied offer their citizens the option of additional insurance to cover such 
additional health service payments. Slovenia offers its citizens voluntary supplementary health insurance, Denmark additional private health insurance, France private health insurance and the UK supplementary private health insurance (Healthcare in Denmark, 2011; International Profiles of Healthcare Systems, 2010, pp. 19, 23-24). As we have already seen in the comparison between the methods of funding healthcare, Denmark and the UK generate around 15\% more public funding for healthcare through taxation than Slovenia and France do from social security resources. This is a field which could be considered good practice for the public funding of healthcare.

In 2011 the Slovenian government adopted a document entitled 'Upgrading the Healthcare System By 2020 - A Step Forward', which introduces sustainability into the healthcare system while maintaining and improving the high level of quality, safety and accessibility of healthcare services for all inhabitants of the country. In 2011 the government also adopted two laws: (1) the Act Amending the Patients' Rights Act, which more specifically and clearly addresses the right to respect patients' time and the right to a second opinion, and which changes or adds the controls exercised by patients' rights representatives; and (2) the Healthcare Databases Act, which establishes a clear, predictable and modern system of procedures for implementing regulatory provisions in the healthcare sector, and provides the legal basis for high-quality, patient-friendly and efficient healthcare performance (Vlada Republike Slovenije/Government of the Republic of Slovenia, 2012).

In addition to these two acts, four draft acts have been drawn up. The first is the draft Healthcare and Health Insurance Act, which aims to ensure adequate funding for those individual elements of the system currently financed from compulsory insurance; it also aims to ensure that public spending is cost-effective and transparent, to increase the balance of funding for health services and, accordingly, to redefine the obligations of the state and the budget to ensure that rights in the field of healthcare can be properly exercised. A further goal of the draft act is the integration of institutions and the introduction of systemic evaluation of health technologies in Slovenia. It redefines certain categories of insured persons and the rights that may be enjoyed by insured persons. The second is the draft Health Services Act, which is based on healthcare values such as universality, fair access, equality of access to highquality health services, the transparency of rights, and public finance sustainability. The basic legal positions are related to the measures that will, on the one hand, ensure healthcare system performance within the context of financial sustainability and, on the other, allow the healthcare system to develop further (Vlada Republike Slovenije/Government of the Republic of Slovenia, 2012).

A draft Pharmacy Services Act has also been compiled. The significant changes it introduces are related to the healthcare network, the networking of public healthcare service providers, an increase in the autonomy of public healthcare institutions, the optimisation of operations, the responsibilities of the managers of institutions, concessions and private self-pay health services, health chambers, healthcare quality and safety, and supervision of healthcare activities. The final draft act is the Medical Expertise Act, which proposes the establishment of a special organisation to provide expertise for the needs of those entities providing social insurance in Slovenia. This will bring a number of advantages, reflected in the streamlining of assessments of the eligibility of insured persons to specific rights, greater professionalism, and the development of medical expertise in line with the model in place in comparable European countries (Vlada Republike Slovenije/Government of the Republic of Slovenia, 2012).

These acts and draft acts are based on the notion of solidarity and on the requirement for Slovenian legislation to comply with EU directives and other national legislation, and are aimed at realising a number of other basic principles of the healthcare system. The basic legal positions are related to measures that will ensure improved healthcare system performance within the context of financial sustainability and facilitate the development of the healthcare system (Vlada Republike Slovenije/Government of the Republic of Slovenia, 2012). The strategic objective of the legislation is to rationalise and reorganise the healthcare system, and to reorganise healthcare insurance (Gregorič Rogelj, 2012).

\section{Changes expected as a result of improvements to the Slovenian healthcare system}

Slovenia has set itself a number of key challenges to improve the healthcare system, and through which the basic principles will be achieved and improvements continue to be made. The key challenges are: preventive activities and the promotion of good health; the financial sustainability of healthcare provision; the efficient management of public funds and the separation of private and public providers; consistent investment in human 
resources and medical technology to meet the needs of the population; and the optimisation of data flow and analysis. The strategic objective pursued by these improvements is a flexible healthcare system that efficiently serves the needs of the population by means of the provision of high-quality and safe healthcare services (Ministrstvo za zdravje Republike Slovenije/Ministry of Health of the Republic of Slovenia, 2011, p. 4; Gregorič Rogelj, 2012).

The solutions proposed by the 'Upgrading the Healthcare System By 2020' document redefine the status of insured persons, make changes to the insurance basis and rates for the funding of the basic basket of healthcare rights, reorganise the Health Insurance Institute of Slovenia, introduce a more precise framework for the proposed introduction of greater autonomy for public healthcare institutions and the separation of public and private healthcare providers, and introduce changes to the oversight exercised by and integration within professional organisations (Ministrstvo za zdravje Republike Slovenije/Ministry of Health of the Republic of Slovenia, 2011, p. 2).

The inadequate definition of the insurance basis, categories of insured persons and contribution rates is another problem for which a solution needs to be sought, since it has led to discrimination between different categories, with workers in the same income bracket paying more than farmers, the self-employed, and pensioners. The new solutions introduce categories of insured persons and insurance basis, which will allow a more even distribution and provide for rates that make contributions consistent with expenditure on individual rights. Another area in which changes are needed is the basket of healthcare rights, which is currently universal. There is a need to define a new basket of healthcare rights vital to the healthcare needs of the population. The new basic basket of healthcare rights will be funded in full from public resources (compulsory health insurance); other rights not included in the basket of basic rights will be covered by private funding. These changes should result in the $86 \%$ coverage of healthcare rights from public funds (from the current figure of $70 \%$ ) and a $2.5 \%$ increase in the contribution rate (Ministrstvo za zdravje Republike Slovenije/Ministry of Health of the Republic of Slovenia, 2011, p. 8; Gregorič Rogelj, 2012).

Changes of a more long-term nature are also proposed, with public healthcare institutions at the primary and secondary levels beginning to integrate horizontally and vertically into knowledge centres. These changes will bring positive economic effects in the area of networking of public institutions, more effective management and optimisation of the management of public institutions with a special emphasis on human resource management. The goal of integration is to optimise costs and improve the quality and accessibility of healthcare services. It also proposes to establish a clear and transparent definition of the provision of public and private healthcare services by public healthcare institutions through the provision of separate accounting and record-keeping for individual healthcare services (Ministrstvo za zdravje Republike Slovenije/Ministry of Health of the Republic of Slovenia, 2011, p. 14, 17-18; Gregorič Rogelj, 2012).

\section{CONCLUSION}

Changes need to be made to the organisation, management, and financing of the Slovenian healthcare system. The current healthcare system is rigid and inflexible, and its financial sustainability is also questionable. Reform is necessary because of demographic changes, changes to the age structure of the population, the rapid development of new medical technologies, drugs and treatments, and globalisation.

Improvements to the healthcare system in Slovenia are based upon a number of fundamental principles: first, the provision of geographical access to healthcare services through decentralisation and the strengthening of regionalisation; second, the provision of high-quality and safe healthcare services; and third, the provision of financial access to services for specific population categories through a redefinition of the basket of healthcare services, in line with the principles of clinical and cost-effectiveness and following changes to the health insurance system. The healthcare system must reduce inequalities in healthcare, but must also become competitive and development-oriented.

Most healthcare funding in Slovenia is provided by public sources - around $71 \%$ of total spending on healthcare. Most of this public funding comes from compulsory health insurance. The healthcare funding system is, 
as in France, based on social security resources. By contrast, Denmark and the UK fund public healthcare through taxation, creating around 15\% more public funding for healthcare in comparison with Slovenia and France. It would be a good idea to examine instances of good practice from Denmark and the UK and to gauge whether they might successfully be transferred to the Slovenian healthcare system.

The Rebalancing of Public Finances Act puts forward a number of proposals for the healthcare sector; they include a reduction in the percentage of healthcare services covered by compulsory health insurance, centralisation of the purchase of medical and technical instruments (public procurement), the classification of drugs to take account of drug interactions, and the working arrangements of healthcare workers under fee-based contracts.

The Slovenian healthcare system needs solutions that introduce sufficient definition to the healthcare insurance basis, the categories of insured persons and the contribution rates. These new solutions would spread the burden more equally, with insurance rates producing contributions that are more consistent with spending on individual rights. The definition of a new basket of healthcare rights is also needed, with this new basic basket being funded entirely from public resources and those rights not included in the basic basket being covered by private funding.

In addition to various healthcare reform measures, Slovenia should use public-private partnerships more often, involving the private sector in investments in healthcare facilities. Public-private partnership is one solution in the field of healthcare which can reduce public spending and bring additional sources of healthcare funding. The UK, for example, has a very long tradition of successful public-private partnership in healthcare; Slovenia could make use of good PPP practice from the UK in its efforts to improve the outlook for healthcare funding.

\section{AUTHOR INFORMATION}

Stanka Setnikar Cankar, Ph.D., is Professor of Public Sector Economics and Dean of the Faculty of Administration. She is the author of many articles and books on public sector economics and is the editor-in-chief of Administration magazine. She has been a member of the NISPACee Steering Committee, and is a member of the Programme Committee of the Annual Conference of Public Administration in Slovenia, IIASIA and EGPA. She manages and participates in a variety of research projects, mostly in the field of public sector reform, public sector reform in healthcare, the measurement of effectiveness in public administration, and cross-border cooperation between Slovenia, Austria, and Italy. She may be contacted at stanka.setnikar-cankar@fu.uni-lj.si (Corresponding author)

Veronika Petkovšek is an assistant at the Department of Public Sector Economics at the Faculty of Administration. Her areas of research interest include public sector economics in the field of healthcare reform, public procurement, and measurements of the efficiency and effectiveness of the public sector. She is also active in cross-border cooperation between Slovenia, Austria, and Italy. She may be contacted at veronika.petkovsek@fu.uni-lj.si

\section{REFERENCES}

1. Devjak, S. \& Benčina, J. (2012). Merjenje učinkovitosti v javnem sektorju, primer mreže slovenskih javnih bolnišnic (Measuring Effectiveness in the Public Sector: The Slovenian Public Hospital Network). In: Vintar, M. (ed.), Klun, M. (ed.) and Kuhelj, A. (ed.), Primerjalni pogled na delovanje izbranih področij javnega sektorja v Sloveniji (A Comparative Study of the Operation of Selected Public Sector Areas in Slovenia). Ljubljana: Fakulteta za upravo (Faculty of Administration).

2. European Health for All Database (HFA-DB). 2012. Retrieved from http://www.euro.who.int/hfadb.

3. Eurostat. Expenditure of Selected Healthcare Functions by Financing Agents in Healthcare. (2012). Eurostat. Retrieved from http://appsso.eurostat.ec.europa.eu/nui/submitViewTableAction.do.

4. $\quad$ Experience with PPP Projects in Healthcare. (2010). Bratislava: PricewaterhouseCoopers.

5. Gregorič Rogelj, E. (2012). Nadgrajevanje zdravstvenega sistema (Upgrading the Healthcare System). Ljubljana: Fakulteta za upravo (Faculty of Administration). Retrieved from http://www.fu.unilj.si/horizont/novice/mag.Gregoric-Rogelj.pptx. 
6. Healthcare in Denmark. (2011). Retrieved from http://www.nyidanmark.dk/enus/Integration/informationguide/healthcare/healthcare in denmark.htm.

7. International Profiles of Healthcare Systems. (2010). New York: The Commonwealth Fund.

8. Ministrstvo za zdravje Republike Slovenije (Ministry of Health of the Republic of Slovenia). (2011). Nadgradnja zdravstvenega sistema do leta 2020 - korak naprej (Upgrading the Healthcare System By 2020 - A Step Forward). Ljubljana: Ministrstvo za zdravje Republike Slovenije. Retrieved from http://www.vlada.si/fileadmin/dokumenti/si/projekti/2011/zdravstvena/NZS_2020_korak_naprej_200711. pdf.

9. Navarro Espigarez, J. L. \& Hernández Torres, E. (2009). Public-Private Partnership as a New Way to Deliver Healthcare Services. XVI Encuentro de Economía Pública.

10. Obvezno zdravstveno zavarovanje v Sloveniji: danes za jutri (Compulsory Health Insurance in Slovenia Today for Tomorrow). (2007). Ljubljana: Zavod za zdravstveno zavarovanje Slovenije (Health Insurance Institute of Slovenia).

11. Poslovno poročilo ZZZS za leto 2009 (2009 Business Report of the Health Insurance Institute of Slovenia). (2010). Ljubljana: Zavod za zdravstveno zavarovanje Slovenije (Health Insurance Institute of Slovenia).

12. Poslovno poročilo ZZZS za leto 2010 (2010 Business Report of the Health Insurance Institute of Slovenia). (2011). Ljubljana: Zavod za zdravstveno zavarovanje Slovenije (Health Insurance Institute of Slovenia).

13. Poslovno poročilo ZZZS za leto 2011 (2011 Business Report of the Health Insurance Institute of Slovenia). (2012). Ljubljana: Zavod za zdravstveno zavarovanje Slovenije (Health Insurance Institute of Slovenia).

14. Prevolnik-Rupel, V., Marušič, D. \& Turk, E. (2012). Sistem zdravstvenega varstva in zdravstvenega zavarovanja v Sloveniji in predvidene spremembe (The Healthcare and Health Insurance System in Slovenia, and the Changes Planned). In: Vintar, M. (ed.), Klun, M. (ed.) and Kuhelj, A. (ed.), Primerjalni pogled na delovanje izbranih področij javnega sektorja v Sloveniji (A Comparative Study of the Operation of Selected Public Sector Areas in Slovenia). Ljubljana: Fakulteta za upravo (Faculty of Administration).

15. Setnikar Cankar, S. \& Petkovšek, V. (2012). Sistem zdravstvenega varstva v Sloveniji in izbranih članicah EU ter javno-zasebno partnerstvo (The Healthcare System in Slovenia and Selected EU Member States, and Public-Private Partnership). In: Vintar, M. (ed.), Klun, M. (ed.) and Kuhelj, A. (ed.), Primerjalni pogled na delovanje izbranih področij javnega sektorja v Sloveniji (A Comparative Study of the Operation of Selected Public Sector Areas in Slovenia). Ljubljana: Fakulteta za upravo (Faculty of Administration).

16. Socialni razgledi 2009 (2009 Social Monitor). (2010). Ljubljana: Urad za makroekonomske analize in razvoj (Institute of Macroeconomic Analysis and Development).

17. Stanimirović, D. \& Vintar, M. (2012). Vloga in vpliv informatizacije na reformo slovenskega zdravstvenega sistema (The Role and Impact of Computerisation in Reform of the Slovenian Healthcare System). In: Vintar, M. (ed.), Klun, M. (ed.) and Kuhelj, A. (ed.), Primerjalni pogled na delovanje izbranih področij javnega sektorja v Sloveniji (A Comparative Study of the Operation of Selected Public Sector Areas in Slovenia). Ljubljana: Fakulteta za upravo (Faculty of Administration).

18. Tajnikar, M. (2009). Predavanje 1. Osnove ekonomike zdravstvenega varstva (Lecture 1 - Basics of Healthcare Economics). Ljubljana: Ekonomska fakulteta (Faculty of Economics). Retrieved from http://www.ef.uni-lj.si/predmeti32/_struktura/izpis.asp?vrsta=2\&id=192337.

19. Tajnikar, M. \& Došenovič Bonča, P. (2010). Kritična analiza organiziranosti zdravstva v Sloveniji (A Critical Analysis of the Organisation of Healthcare in Slovenia). Ljubljana: Ekonomska fakulteta (Faculty of Economics).

20. Vlada Republike Slovenije (Government of the Republic of Slovenia). (2012). Nadgradnja zdravstvenega sistema (Upgrading the Healthcare System). Ljubljana: Vlada Republike Slovenije. Retrieved from http://www.vlada.si/si/teme in_projekti/izhod_iz krize/strukturni_ukrepi/nadgradnja_zdravstvenega siste $\underline{\mathrm{mal}}$. 